\title{
Analisis Kemampuan Penalaran Matematis Peserta Didik dengan Penyajian Masalah Open-Ended Pada Pembelajaran Daring
}

Siti Sundari Agustin, Sigid Edy Purwanto, Samsul Ma'arif, Joko Soebagyo

How to cite : Agustin, S., S., Purwanto, S., E. Ma'arif, S., Soebagyo, J., 2021. Analisis Kemampuan Penalaran Matematis Peserta Didik dengan Penyajian Masalah Open-Ended Pada Pembelajaran Daring. Kognitif: Jurnal Riset HOTS Pendidikan Matematika. 1(1). 66-80. https://doi.org/10.51574/kognitif.v1i1.19

To link to this article : https://doi.org/10.51574/kognitif.v1i1.19

Opened Access Article

Published Online on 1 Juni 2021

Submit your paper to this journal 


\title{
Analisis Kemampuan Penalaran Matematis Peserta Didik dengan Penyajian Masalah Open-Ended Pada Pembelajaran Daring
}

\author{
Siti Sundari Agustin ${ }^{1}$, Sigid Edy Purwanto ${ }^{1}$, Samsul Ma'arif ${ }^{1}$, Joko Soebagyo ${ }^{1}$ \\ ${ }^{1}$ Pendidikan Matematika, Universitas Muhammadiyah Prof. DR. Hamka, Indonesia
}

\begin{tabular}{l} 
Article Info \\
\hline Article history: \\
Received Apr 1, 2021 \\
Accepted Apr 29, 2021 \\
Published Online Juni 1, 2021 \\
\hline
\end{tabular}

Keywords:

Penlaran Matematis

Masalah Open-Ended

Pembelajaran Daring

\begin{abstract}
Tujuan penelitian ini untuk menganalisis kemampuan penalaran matematis peserta didik dengan penyajian masalahan open-ended pada pembelajaran daring. Metode penelitian yang digunakan adalah deskriptif dengan pendekatan kualitatif. Subjek penelitian ini adalah peserta didik kelas VIII-A SMP Negeri 52 Jakarta sebanyak 24 peserta didik. Untuk teknik pengumpulan data penelitian ini adalah tes tertulis dan wawancara. Sedangkan teknik analisis data menggunakan penskoran, penyajian data dan mendeskripsikan serta menarik kesimpulan dari data yang telah dikumpulkan. Hasil dari penelitian ini adalah kemampuan penalaran matematis peserta didik pada pembelajaran daring sangat ditentukan ketika peserta didik menyelesaikan permasalahan, khususnya permasalahan open-ended. Hal ini dapat ditunjukkan dari ketercapaian indikator menarik kesimpulan yang logis dengan kategori tinggi, membuat generalisasi dengan kategori sangat tinggi, memeriksa kesahihan dari pernyataan dengan kategori tinggi, memberikan alasan atau bukti terhadap kebenaran solusi dengan kategori sangat tinggi, dan menyusun pembuktian langsung dengan kategori tinggi. Dari ketercapaian indikator-indikator tersebut maka dapat disimpulkan bahwa rata-rata kemampuan penalaran matematis peserta didik dengan penyajian masalah open-ended pada pembelajaran daring termasuk kategori tinggi dengan persentase $76 \%$.
\end{abstract}

Copyright () 2021 Kognitif. All rights reserved.

\section{Corresponding Author:}

Sigid Edy Purwanto,

Pendidikan Matematika,

Universitas Muhammadiyah Prof. DR. Hamka

Email: sigid@uhamka.ac.id

\section{Pendahuluan}

Wabah corona virus disease 2019 (Covid-19) yang telah melanda beberapa negara di dunia, maka berdampak pada proses pembelajaran disekolah. Dimana banyak sekolah sekarang menggunakan proses pembelajaran daring yang menggunakan berbagai macam media pembelajaran sebagai pendukung pembelajaran. Pembelajaran secara daring sebagai alternatif pengganti pembelajaran tatap muka. Hal ini sesuai dengan pendapat (Santosa et al., 2020) yang mengatakan bahwa pembelajaran daring atau E-learning dengan memanfaatkan web untuk 
mengaksesnya menjadi salah satu sarana belajar yang dikenal dengan Learing Management System (LMS).

Pembelajaran daring atau sering disebut dengan pembelajaran online dapat terhubung dengan peserta didik dan guru sebagai fasilitatornya walaupun secara fisik terpisah atau berjauhan namun dapat saling berkomunikasi, berinteraksi atau berkolaborasi dengan menggunakan berbagai macam media pembelajaran untuk membantu proses pembelajaran. Me Nabilah et al (2021) mengatakan bahwa pembelajaran yang dilakukan secara online dapat didefinisikan dengan pembelajaran dilakukan oleh guru dan peserta didik yang dipisahkan oleh ruang dan waktu.

Salah satu mata pelajaran yang dilakukan pembelajaran secara daring adalah matematika. Matematika sangat berhubungan erat dengan banyak hal salah satunya kemampuan yang harus dimiliki oleh peserta didik (Octaviani et al., 2021). Dalam belajar matematika peserta didik dituntut untuk memiliki beberapa kemampuan. Menurut NCTM atau National Council of Teacher of Mathematics dalam (Indriani et al., 2018) mengatakan bahwa terdapat lima kemampuan matematis yang harus dikembangkan antara lain: koneksi (connections), penalaran (reasoning), komunikasi (communications), pemecahan masalah (problem solving) dan representasi (representations).

Menurut Lithner dalam (Rizqi \& Surya, 2017), mengatakan bahwa penalaran adalah cara berpikir untuk mendapatkan suatu pernyataan dan kesimpulan dalam menyelesaikan masalah yang tidak selalu berasal dari logika formal sehingga tidak terbatas pada pembuktian. Maka dapat dikatakan penalaran atau reasoning merupakan proses berpikir yang menggunakan nalar untuk dapat menghasilkan sebuah kesimpulan dalam pemecahan suatu masalah.

Hal ini sesuai dengan pendapat Sa'adah dalam (Faradillah, 2018) mengatakan bahwa terdapat dua hal yang tidak bisa dipisahkan dalam pembelajaran matematika yaitu materi matematika dan penalaran matematis. Dimana dalam materi matematika dapat dipahami dengan penalaran sedangkan penalaran dipahami melalui proses pembelajaran materi matematika. Gürbüz \& Erdem (2016) mengatakan bahwa penalaran matematis berasal dari pemikiran yang logis sehingga menghasilkan sebuah kesimpulan.

Penalaran matematika merupakan suatu fondasi dalam membangun ilmu matematika. Hal ini sesuai dengan pendapat (Danissman \& Erginer, 2017) yang mengatakan bahwa matematika tidak hanya mengajarkan sebuah angka, operasi, aljabar, geometri dan pengukuran luas tetapi penalaran, menggunakan pemikirannya yang logis serta mampu membuat kesimpulan.

Berdasarkan penjelasan diatas, dapat di simpulkan bahwa kemampuan penalaran matematis sangat penting dimiliki oleh peserta didik. Konita et al (2019) menyatakan bahwa kemampuan penalaran matematis adalah kemampuan berpikir peserta didik yang menghubungkan dengan sebuah fakta sehingga menghasilkan kesimpulan atau hasil dari permasalahan matematis.

Kemampuan penalaran matematis peserta didik dapat ditingkatkan dengan guru memberikan masalah yang bersifat open-ended melalui sebuah soal matematika dengan tujuan agar dapat melatih daya penalaran matematis peserta didik. Tandililing (2013), masalah openended merupakan masalah yang diberikan sehingga memiliki kemungkinan beragam jawaban benar baik ditinjau dari cara penyelesaian maupun hasil akhir. Hal ini sesuai dengan pendapat (Syutaridho, 2015) yang menyatakan bahwa open-ended merupakan suatu masalah atau soal yang memiliki penyelesaian masalah lebih dari satu strategi.

Pada penelitian ini untuk menganalisis kemampuan penalaran matematis peserta didik dengan penyajian masalah open-ended pada pembelajaran daring. Hal ini didasari oleh pernyataan diatas bahwa adanya wabah covid-19 banyak pihak sekolah yang melalukan pembelajaran secara daring dimana kemampuan penalaran matematis sangat diperlukan dan 
sangat ditentukan apabila menemui soal matematika yang memiliki lebih dari satu jawaban atau satu cara penyelesaian yang disebut dengan open-ended.

\section{Kemampuan penalaran matematis}

Penyebab paling utama dari kesulitan belajar dan berprestasi dalam bidang matematika adalah peserta didik terlalu sering menggunakan hafalan dan penalaran matematis dalam pembelajaran (Boesen et al., 2010). Keyakinan dalam bernalar sudah menjadi bentuk pemikiran yang ada pada diri peserta didik.

Penalaran merupakan suatu pemecahan masalah dan pemikiran analitis yang melibatkan manipulasi rangsangan verbal untuk menghasilkan suatu kesimpulan (Robbins, 2011). Penalaran matematika didefinisikan sebagai suatu pembuatan konsep untuk menarik kesimpulan yang berasal dari cara penyelesaian matematika (Olteanu, 2020). Penalaran matematis untuk membuat dugaan dan menghasilkan suatu kesimpulan dibagi menjadi dua kategori yaitu penalaran deduktif dan penalaran induktif (Psycharis \& Kallia, 2017).

Penalaran induktif dan penalaran deduktif sangat berperan penting untuk saling melengkapi penalaran matematis. Hal ini sejalan dengan pendapat (Morris, 2002) dimana suatu dugaan dihasilkan melalui generalisasi dari penalaran induktif sedangkan untuk dibuktikan dengan kesimpulan maka menggunakan penalaran deduktif.

Penalaran matematika didefinisikan dengan faktor utama dalam membangun ilmu matematika. Menurut Fisher et al (2019) mengatakan bahwa penalaran matematis termaksud kedalam inti dari matematika yang apabila kemampuan penalaran baik maka akan menggambarkan kemampuan matematisnya yang baik pula.

Didalam kemampuan penalaran matematis terdapat beberapa indikator yang harus dicapai oleh peserta didik. Sukirwan et al (2018) dalam penalaran berkaitan dengan lima proses yaitu menggeneralisasi, merefleksikan, meyakinkan, merepsentasikan dan menarik kesimpulan berdasarkan fakta.

Suatu penalaran matematis termaksud kedalam kemampuan untuk menganalisis masalah, mengidentifikasi pola dan menerapkan logika yang berkaitan dengan kemampuan berpikir peserta didik (Partanen et al., 2020). Maka dapat disimpulkan bahwa kemampuan penalaran matematis adalah kemampuan yang dimiliki oleh peserta didik untuk menghubungkan beberapa fakta sehingga dapat menghasilkan sebuah kesimpulan yang logis. Hal ini didukung dengan pendapat (Rohana, 2015) yang mengatakan bahwa penalaran matematis merupakan suatu proses dalam menarik kesimpulkan berdasarkan fakta melalui pemikiran yang kritis dalam menyelesaikan suatu masalah matematika.

Didalam menyelesaikan masalah matematika tidak terlepas dari sebuah penalaran yang dimiliki oleh peserta didik. Hal ini didasari bahwa penalaran dikaitkan dengan masalah matematika seperti pada masalah perhitungan yang melibatkan pengetahuan aljabar dan pecahan (Ikram et al., 2021).

Beberapa studi yang mengatakan bahwa kemampuan penalaran matematis peserta didik yang dimiliki masih tergolong rendah. Menurut Flegas \& Charalampos (2013) menyebutkan bahwa dari semua tingkatan pendidikan dasar hingga pendidikan tinggi menghadapi kesulitan ketika membenarkan suatu dugaan dalam matematika. Menurut Basturk (2010) mengatakan bahwa dalam menyelesaikan soal para peserta didik lebih berkonsentrasi pada menghafal bukti dengan cara menulis ulang bekali-kali untuk mengingat jawaban tersebut.

\section{Masalah Open-Ended}

Pada pembelajaran matematika disekolah, guru hanya memberikan soal yang memiliki satu jawaban benar mengakibatkan pandangan peserta didik bahwa masalah matematika hanya 
dapat diselesaikan dengan satu cara penyelesaian. Maka masalah open-ended menjadi tidak umum dalam materi pembelajaran matematika disekolah (Kosyvas, 2016).

Untuk mengatasi pandangan peserta didik tersebut maka guru harus memberikan soal yang bersifat open-ended dalam pembelajaran. Hal ini sejalan dengan pendapat (Hasanah \& Karyati, 2018) yang mengatakan bahwa pemberian masalah open-ended akan membawa peserta didik dalam menyelesaiakan masalah tersebut dengan berbagai cara dan kemungkinan untuk jawaban benar yang akan meningkatkan potensi intelektual serta pengalaman bagi peserta didik untuk menemukan sesuatu hal yang baru.

Dalam memberikan masalah open-ended kepada peserta didik memiliki banyak manfaat. Karena jenis pertanyaan dalam masalah open-ended akan diselesaikan dengan pendekatan yang berbeda dan memberikan kesempatan untuk lebih kreatif dalam memberikan tanggapan (Sole, 2016). Hal ini sejalan dengan pendapat (Imai, 2000) yang mengatakan bahwa dalam pemberian soal open-ended akan meningkatkan kreativitas peserta didik dalam matematika.

Pada penilaian matematika yang peserta didik lakukan lebih menekankan kepada masalah matematika yang membutuhkan jawaban lebih dari satu cara penyelesaian. Sejalan dengan pendapat (Tan \& Maker, 2020) masalah open-ended terdiri dari masalah yang membutuh lebih dari satu jawaban benar.

Menurut Douglas et al (2012) masalah open-ended bersifat kompleks, abstrak dan memiliki beberapa kemungkinan solusi dalam menyelesaikan masalah matematika. Berdasarkan penjelasan diatas, maka dapat disimpulkan bahwa pemberian masalah open-ended adalah memberikan masalah dalam bentuk soal yang memiliki cara penyelesaian lebih dari satu cara atau satu jawaban benar.

\section{Pembelajaran Daring}

Pembelajaran secara daring atau disebut dengan pembelajaran online sudah dikembangkan sejak abad 21 ini, dikarenakan perkembangan teknologi informasi dan komunikasi yang semakin canggih. Pembelajaran daring bisa juga disebut dengan pembelajaran jarak jauh. Menurut Kosiret (2021) mengatakan bahwa pembelajaran jarak jauh yaitu pembelajaran yang dilakukan tidak bertemu atau bertatap muka secara langsung dikelas karena pembelajaran hanya berbasis internet.

Didalam proses pembelajaran memerlukan teknologi yang semakin canggih. Hal ini sesuai dengan pendapat (Argarwal \& Kaushik, 2020) yang mengatakan bahwa E-Learning merupakan teknologi infomasi yang digunakan untuk meningkatkan kualitas pendidikan.

Untuk meningkatkan kualitas pendidikan dalam proses pembelajaran maka diperlukan fasilitas yang mendukung. Littlejohn (2003) E-Learning dapat dikatakan bahwa pembelajaran dilakukan dengan berbasis web, ruang kelas virtual dan kolaborasi digital yang merujuk untuk penyampaian materi pembelajaran.

Pembelajaran daring dapat terhubung dengan peserta didik dan guru sebagai fasilitatornya walaupun secara fisik terpisah atau berjauhan namun dapat saling berkomunikasi, berinteraksi atau berkolaborasi dengan menggunakan berbagai macam media pembelajaran untuk membantu proses pembelajaran. Beberapa media yang digunakan untuk membantu selama proses pembelajaran daring, seperti kelas-kelas virtual yang menggunakan layanan Google Classroom, Edmodo, schoology dan aplikasi pesan instan seperti WhatsApp. Kemudian didalam pembelajaran daring telah banyak universitas yang menggunakan bahkan untuk penelitian (Dharmawansa et al., 2013).

Pembelajaran secara daring sangat memerlukan Learning Management System (LMS) untuk berjalannya proses pembelajaran yang baik. Karena apabila penggunaan LMS rendah maka akses teknologi untuk ke internet akan berkecepatan rendah pula yang akan menyebabkan proses pembelajaran yang menjadi tidak maksimal (Johns \& Mills, 2021). 
Dalam pembelajaran daring ini memiliki beberapa kelemahan dalam proses pembelajaran. Hal ini sependapat dengan (Landrum et al., 2020) yang mengatakan bahwa motivasi untuk belajar semakin turun dan fasilitas seperti paket data internet yang kurang memadai mengakibatkan proses pembelajaran daring ini semakin tidak kondusif dan tidak efisien.

Berdasarkan penjelasan diatas maka dapat disimpulkan bahwa pembelajaran daring atau E-learning adalah pembelajaran yang dilakukan secara online melalui web atau aplikasi untuk mengaksesnya sebagai media pembelajaran pengganti pembelajaran tatap muka.

\section{Metode}

Penelitian ini menggunakan pendekatan kualitatif dengan metode deskriptif kualitatif. Hal itu dipilih karena dapat mendeskripsikan peserta didik dengan tingkat kemampuan penalaran matematis dengan penyajian masalah open-ended. Subjek penelitian ini adalah peserta didik kelas VIII-A SMP Negeri 52 Jakarta sebanyak 24 peserta didik.

Untuk teknik pengumpulan data yang digunakan adalah tes tertulis dan wawancara. Sedangkan teknik analisis data menggunakan penskoran, penyajian data dan mendeskripsikan serta menarik kesimpulan dari data yang telah dikumpulkan. Data analisis dilakukan berdasarkan pencapaian indikator untuk melihat tingkat kemampuan penalaran matematis peserta didik dengan penyajian masalah open-ended.

Indikator yang diukur dalam penelitian ini adalah (1) Menarik kesimpulan yang logis, (2) Membuat generalisasi, (3) Memeriksa kesahihan dari pernyataan, (4) Memberikan alasan atau bukti terhadap kebenaran solusi, dan (5) Menyusun pembuktian langsung.

Setelah mendapatkan skor hasil tes tertulis kemampuan penalaran matematis, kategori penilaian adalah diberikan untuk menentukan tingkat peserta didik kemampuan penalaran matematis dengan soal open-ended. Kategori skor tes peserta didik dikategorikan dengan skala lima berbasis. Dapat dilihat pada tabel 1.

Tabel 1, Kategori Kemampuan Penalaran Matematis

\begin{tabular}{cc}
\hline Persentase Skor & Kategori \\
\hline $81 \%-100 \%$ & Sangat Tinggi \\
$61 \%-80 \%$ & Tinggi \\
$41 \%-60 \%$ & Sedang \\
$21 \%-40 \%$ & Rendah \\
$0 \%-20 \%$ & Sangat Rendah \\
\hline
\end{tabular}

Dalam penelitian ini peneliti hanya mendeskripsikan hasil jawaban matematika data kemampuan penalaran matematis di waktu belajar yang sudah dibatasi untuk mengerjakan tes tertulis yaitu pada pukul 07.00 - 09.00 WIB dan melakukan wawancara pada siang hari melalui aplikasi zoom meeting pada pukul $13.00-15.00 \mathrm{WIB}$. 


\section{Hasil Penelitian dan Pembahasan}

Hasil penyelesaian matematika peserta didik untuk tes kemampuan penalaran matematis yang dilakukan kepada peserta didik secara online dengan memberikan link google form dan wawancara melalui zoom meting. Terdapat 5 soal uraian yang diberikan kepada peserta didik dimana setiap masalah mengukur satu indikator kemampuan penalaran matematis melalui cara penyelesaian yang lebih dari satu. Hasil penyelesaian matematika data kemampuan penalaran matematis dapat dilihat dalam tabel 2.

Tabel 2 Kategori Ketercapaian Skor Indikator Kemampuan Penalaran Matematis terhadap Jumlah Siswa

\begin{tabular}{|c|c|c|c|c|c|c|c|c|c|}
\hline \multirow{2}{*}{$\begin{array}{l}\text { Nomor } \\
\text { Soal }\end{array}$} & \multirow{2}{*}{$\begin{array}{l}\text { Indikator } \\
\text { Penalaran } \\
\text { Matematis }\end{array}$} & \multicolumn{5}{|c|}{$\begin{array}{l}\text { Banyak Peserta didik } \\
\text { yang memperoleh skor }\end{array}$} & \multirow[t]{2}{*}{ Jumlah } & \multirow{2}{*}{$\begin{array}{l}\text { Persentase } \\
\text { Ketercapaian } \\
\text { Indikator }\end{array}$} & \multirow[t]{2}{*}{ Kategori } \\
\hline & & 4 & 3 & 2 & 1 & 0 & & & \\
\hline 1 & $\begin{array}{c}\text { Menarik } \\
\text { kesimpulan } \\
\text { yang logis }\end{array}$ & 11 & 8 & 1 & 4 & 0 & 24 & $77 \%$ & Tinggi \\
\hline 2 & $\begin{array}{l}\text { Membuat } \\
\text { generalisasi }\end{array}$ & 16 & 4 & 2 & 2 & 0 & 24 & $85 \%$ & $\begin{array}{l}\text { Sangat } \\
\text { Tinggi }\end{array}$ \\
\hline 3 & $\begin{array}{l}\text { Memeriksa } \\
\text { kesahihan } \\
\text { dari } \\
\text { pernyataan }\end{array}$ & 12 & 1 & 3 & 8 & 0 & 24 & $68 \%$ & Tinggi \\
\hline 4 & $\begin{array}{l}\text { Memberikan } \\
\text { alasan atau } \\
\text { bukti } \\
\text { terhadap } \\
\text { kebenaran } \\
\text { solusi }\end{array}$ & 20 & 0 & 3 & 1 & 0 & 24 & $91 \%$ & $\begin{array}{l}\text { Sangat } \\
\text { Tinggi }\end{array}$ \\
\hline 5 & $\begin{array}{l}\text { Menyusun } \\
\text { pembuktian } \\
\text { langsung }\end{array}$ & 5 & 8 & 6 & 3 & 2 & 24 & $61 \%$ & Tinggi \\
\hline
\end{tabular}

Data pada Tabel 2 menunjukan bahwa hasil penyelesaian peserta didik dalam mengerjakan soal nomor satu dengan indikator menarik kesimpulan yang logis dari 24 peserta didik terdapat 11 peserta didik yang mendapatkan skor 4 . Maka dapat dikatakan bahwa peserta didik tidak mengalami kesulitan dalam menyelesaikan soal, karena peserta didik sudah paham dan mengerti apa yang diketahui dan ditanya dalam soal. Peserta didik sudah mampu menyelesaikan soal kemampuan penalaran untuk indikator menarik kesimpulan yang logis dengan tepat. Dilihat dari persentase ketercapaian indikatornya yaitu mencapai $77 \%$, ini berarti untuk indikator menarik kesimpulan yang logis, kemampuan penalaran matematis siswa termasuk kedalam kategori tinggi.

Hasil penyelesaian peserta didik dalam mengerjakan soal nomor dua dengan indikator membuat generalisasi, dari 24 peserta didik terdapat 16 peserta didik yang mendapatkan skor 
4. Maka dapat dikatakan bahwa peserta didik tidak mengalami kesulitan dalam menyelesaikan soal, karena peserta didik sudah paham dan mengerti apa yang diketahui dan ditanya dalam soal. Peserta didik sudah mampu menyelesaikan soal kemampuan penalaran untuk indikator membuat generalisasi dengan tepat. Dilihat dari persentase ketercapaian indikatornya yaitu mencapai $85 \%$, ini berarti untuk indikator membuat generalisasi, kemampuan penalaran matematis siswa termasuk kedalam kategori sangat tinggi.

Hasil jawaban peserta didik dalam menyelesaikan soal nomor tiga dengan indikator memeriksa kesahihan dari pernyataan, dari 24 peserta didik terdapat 12 peserta didik yang mendapatkan skor 4. Maka dapat dikatakan bahwa peserta didik tidak mengalami kesulitan dalam menyelesaikan soal, karena peserta didik sudah paham dan mengerti apa yang diketahui dan ditanya dalam soal. Peserta didik sudah mampu menyelesaikan soal kemampuan penalaran untuk indikator memeriksa kesahihan dari pernyataan dengan tepat. Dilihat dari persentase ketercapaian indikatornya yaitu mencapai $68 \%$, ini berarti untuk indikator memeriksa kesahihan dari pernyataan, kemampuan penalaran matematis siswa termasuk kedalam kategori tinggi.

Hasil jawaban peserta didik dalam menyelesaikan soal nomor empat dengan indikator memberikan alasan atau bukti terhadap kebenaran solusi, dari 24 peserta didik terdapat 20 peserta didik yang mendapatkan skor 4. Maka dapat dikatakan bahwa peserta didik tidak mengalami kesulitan dalam menyelesaikan soal, karena peserta didik sudah paham dan mengerti apa yang diketahui dan ditanya dalam soal. Peserta didik sudah mampu menyelesaikan soal kemampuan penalaran untuk indikator memberikan alasan atau bukti terhadap kebenaran solusi dengan tepat. Dilihat dari persentase ketercapaian indikatornya yaitu mencapai $91 \%$, ini berarti untuk indikator memberikan alasan atau bukti terhadap kebenaran solusi, kemampuan penalaran matematis siswa termasuk kedalam kategori sangat tinggi.

Hasil jawaban peserta didik dalam menyelesaikan soal nomor lima dengan indikator menyusun pembuktian langsung, dari 24 peserta didik terdapat 5 peserta didik yang mendapatkan skor 4 . Bahkan terdapat peserta didik yang tidak menjawab soal nomor lima berjumlah 2 peserta didik. Maka dapat dikatakan bahwa peserta didik mengalami kebinggungan dan kesulitan dalam menyelesaikan soal tersebut karena tidak mengetahui pembuktian dari rumus Pythagoras. Peserta didik kurang mampu menyelesaikan soal kemampuan penalaran untuk indikator menyusun pembuktian langsung dengan tepat. Dilihat dari persentase ketercapaian indikatornya yaitu mencapai $61 \%$, ini berarti untuk indikator menyusun pembuktian langsung, kemampuan penalaran matematis siswa termasuk kedalam kategori tinggi.

Tabel 3. Kategori Rata-rata Kemampuan Penalaran Matematis Peserta Didik

\begin{tabular}{ccccccc}
\hline Indikator & 1 & 2 & 3 & 4 & 5 & Rata-Rata \\
\hline Persentase & $77 \%$ & $85 \%$ & $68 \%$ & $91 \%$ & $61 \%$ & $76 \%$ \\
Kategori & Tinggi & $\begin{array}{c}\text { Sangat } \\
\text { Tinggi }\end{array}$ & Tinggi & Sangat Tiggi & Tinggi & Tinggi \\
\hline
\end{tabular}

Pada Tabel 3 terlihat bahwa dalam menyelesaikan soal open-ended, rata-rata kemampuan penalaran matematis peserta didik termasuk kategori tinggi. Maka dapat dikatakan peserta didik mampu menggunakan daya nalarnya dengan baik dalam menyelesaikan permasalahan open- ended yang diberikan. Analisis jawaban peserta didik berdasarkan indikator adalah: 


\section{Menarik kesimpulan yang logis}

Dalam mengerjakan soal nomor satu peserta didik telah memenuhi indikator "menarik kesimpulan yang logis" dalam menyelesaikan soal open-ended yang memiliki banyak cara untuk menjawabnya. Jawaban peserta didik ini pada Gambar 1 diberikan skor 4 dengan soal "Putri dan Angel diberikan tugas oleh gurunya untuk mencari jarak terdekat antara rumah mereka dengan rumah Mery, teman satu kelasnya. Jika Putri ingin pergi ke rumah Mery, pertama-tama Putri harus pergi ke arah timur dari rumahnya sejauh $3 \mathrm{~km}$. Kemudian berbelok ke arah selatan sejauh 4 km. Sedangkan jika Angel ingin pergi kerumah Mery, pertama-tama harus pergi kearah timur rumahnya sejauh $6 \mathrm{~km}$. Kemudian berbelok kearah utara sejauh $8 \mathrm{~km}$. Maka simpulkan jarak terdekat antara rumah Putri dan Angel dengan rumah Mery. Jelaskan alasan yang mendasari kesimpulan tersebut ?’. Karena peserta didik telah mampu menyelesaikan masalah dengan menentukan salah satu panjang garis miring sehingga dapat menyimpulkan jarak tedekat dengan benar.

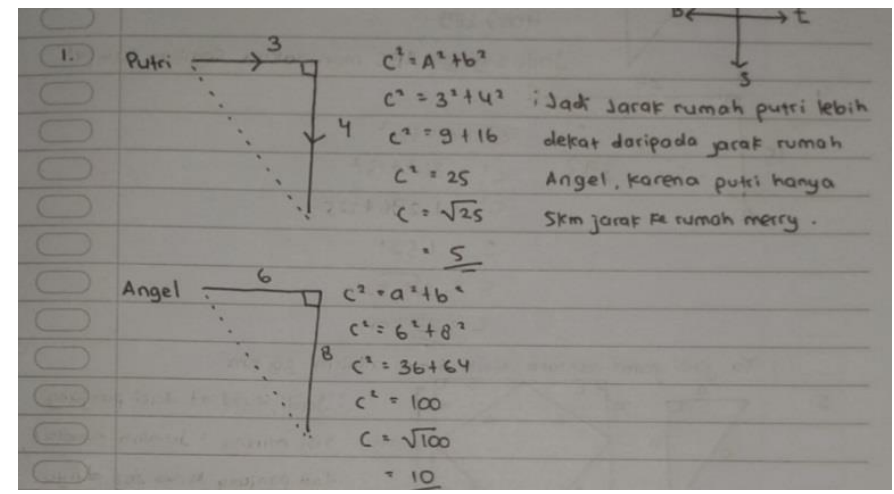

Gambar 1. Hasil Jawaban Siswa yang Diberi Skor 4

Terkait dengan jawaban tersebut, dapat ditunjukan dalam wawancara dibawah ini :

$\mathrm{P} \quad$ : Apa yang kamu ketahui dari soal No 1 tersebut?

S1 : Dari yang saya baca soal no 1 itu kak, putri pergi kearah timur sejauh $3 \mathrm{~km}$ dan ke arah selatan sejauh $4 \mathrm{~km}$. Sedangkan angel pergi ke timur sejauh $6 \mathrm{~km}$ dan kearah utara sejauh $8 \mathrm{~km}$. Lalu ditanyakan lebih dekat rumah siapa antara putri dengan angel kerumah mery kak.

$\mathrm{P} \quad$ : Apa yang dapat kamu simpulkan dari soal tersebut?

S1 : Kesimpulan menurut saya kak, lebih dekat rumah putri ke rumah mery karena sejauh $5 \mathrm{~km}$ sedangkan dari rumah angel sejauh $10 \mathrm{~km}$.

P : Coba, jelaskan alasan kamu. Kenapa dapat menyimpulkan seperti itu.

S1 : Karena setelah saya hitung menggunakan rumus Pythagoras didapatkan rumah putri $5 \mathrm{~km}$ kak, sedangkan rumah angel $10 \mathrm{~km}$.

Berdasarkan analisis hasil jawaban dan wawancara dengan S1 dapat disimpulkan bahwa S1 dalam menyelesaikan permasalahan no 1 , memenuhi indikator penalaran matematis yaitu Menarik kesimpulan yang logis dan masalah open-ended.

\section{Membuat generalisasi}

Dalam mengerjakan soal nomor dua peserta didik telah memenuhi indikator "membuat generalisasi" dalam menyelesaikan soal open-ended yang memiliki banyak cara untuk menjawabnya. Jawaban peserta didik ini pada Gambar 2 diberikan skor 4 dengan soal "Dibawah ini merupakan barisan triple Pythagoras :
$3,4,5$
(Baris Pertama)
$6,8,10$
(Baris Kedua)
$9,12,15$
(Baris Ketiga)

Jika diteruskan sampai baris ke-n, maka dapatkah kalian membuat generalisasi dari pola barisan tersebut ? Berapakah bilangan triple Pythagoras pada baris ke-10 ?”. Karena peserta 
didik telah mampu menyelesaikan masalah dengan menentukan triple pythagoras pada baris ke-10 dengan membuat generalisasinya terlebih dahulu dengan benar.

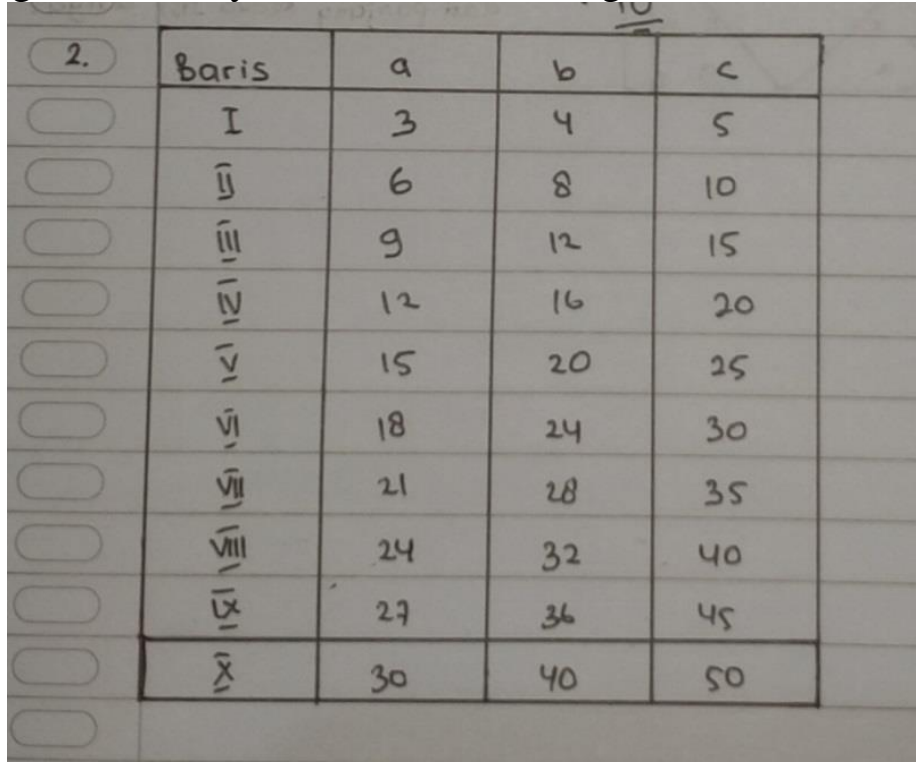

\section{Gambar 2. Hasil Jawaban Peserta Didik yang Diberi Skor 4}

Terkait dengan jawaban tersebut, dapat ditunjukan dalam wawancara dibawah ini :

P : Sudah pernah melihat soal no.2 seperti ini sebelumnya?

S1 : Belum pernah melihat soal seperti itu kak sebelumnya.

$\mathrm{P} \quad$ : Apa yang ditanyakan dalam soal tersebut?

S1 : Menentukan triple pada baris ke-10 kak.

$\mathrm{P} \quad$ : Bagaimana generalisasi untuk sampai baris ke-10?

S1 : Pada bilangan pertama kelipatan 3, bilangan kedua kelipatan 4 dan bilangan ketiga kelipatan 5.

$\mathrm{P} \quad$ : Lalu bagaimana kalau sampai baris ke-n ?

S1 : Berarti dikalikan dengan $n$ kak, dan didapatkan 3n,4n, 5n.

P : Berapakah nilai pada baris ke-10?

S1 : Karena dikalikan dengan 10 berarti 30,40,50 kak

Berdasarkan analisis hasil jawaban dan wawancara dengan S1 dapat disimpulkan bahwa S1 dalam menyelesaikan permasalahan no 2, memenuhi indikator penalaran matematis yaitu Membuat generalisasi dan masalah open-ended.

\section{Memeriksa kesahihan dari pernyataan}

Dalam mengerjakan soal nomor tiga peserta didik telah memenuhi indikator "memeriksa kesahihan dari pernyataan" dalam menyelesaikan soal open-ended yang memiliki banyak cara untuk menjawabnya. Jawaban peserta didik ini pada Gambar 3 diberikan skor 4 dengan soal "Suatu segitiga ABC dengan siku-siku berada di B. Jika diketahui panjang sisi AB $=8 \mathrm{~cm}, \mathrm{BC}=15 \mathrm{~cm}$, dan $\mathrm{AC}=20 \mathrm{~cm}$. Apakah berbentuk segitiga tumpul ? Buktikan!". Karena peserta didik telah mampu menyelesaikan masalah dengan menentukan jenis segitiga tersebut dengan benar. 


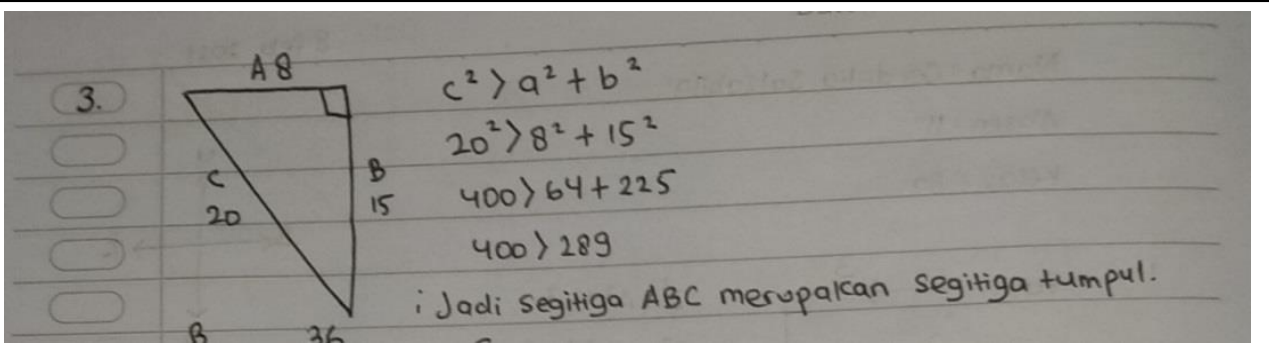

Gambar 3. Hasil Jawaban Peserta Didik yang Diberi Skor 4

Terkait dengan jawaban tersebut, dapat ditunjukan dalam wawancara dibawah ini :

$\mathrm{P} \quad$ : Informasi apa yang kamu dapat untuk soal no 3 tersebut ?

S1 : Menentukan segitiga tersebut tumpul atau bukan.

$\mathrm{P} \quad$ : Apakah segitiga $\mathrm{ABC}$ tersebut berbentuk segitiga tumpul ?

S1 : Iya kak berbentuk segitiga tumpul.

P : Coba jelaskan, Kenapa dikatakan segitiga tersebut tumpul ?

S1 : Karena nilai $\mathrm{c}$ adalah 20 sedangkan nilai a adalah 8 dan $\mathrm{b}$ adalah 15. Apabila dikuadrat dan hasil $\mathrm{a}+\mathrm{b}$ nya lebih kecil daripada hasil $\mathrm{c}$ dikuadratin maka segitiga tumpul. Sedangkan $\mathrm{a}+\mathrm{b}$ lebih besar daripada $\mathrm{c}$ dikuadratin maka segitiga lancip kak.

Berdasarkan analisis hasil jawaban dan wawancara dengan S1 dapat disimpulkan bahwa S1 dalam menyelesaikan permasalahan no 3, memenuhi indikator penalaran matematis yaitu Memeriksa kesahihan dari pernyataan dan masalah open-ended.

\section{Memberikan alasan atau bukti terhadap kebenaran solusi}

Dalam mengerjakan soal nomor empat peserta didik telah memenuhi indikator "memberikan alasan atau bukti terhadap kebenaran solusi" dalam menyelesaikan soal openended yang memiliki banyak cara untuk menjawabnya. Jawaban peserta didik ini pada Gambar 4 diberikan skor 4 dengan soal "Suatu kapal berlayar dari pelabuhan A ke pelabuhan B sejauh $15 \mathrm{~km}$ menuju arah utara. Setelah tiba pada Pelabuhan B, kapal tersebut berlayar kembali sejauh $36 \mathrm{~km}$ menuju arah timur. Apakah jarak antara pelabuhan A dengan titik akhir adalah $39 \mathrm{~km}$ ? Jelaskan pendapatmu!". Karena peserta didik telah mampu menyelesaikan masalah dengan menghitung salah satu sisi miring segitiga dengan benar.

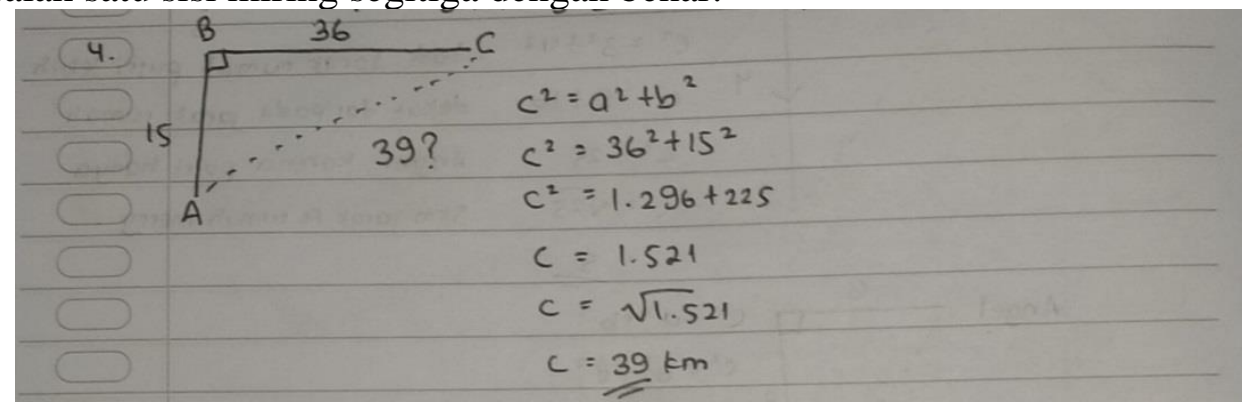

Gambar 4. Hasil Jawaban Peserta Didik yang Diberi Skor 4

Terkait dengan jawaban tersebut, dapat ditunjukan dalam wawancara dibawah ini :

$\mathrm{P} \quad$ : Apa yang diketahui dari soal no 4 tersebut?

S1 : Jarak perahu a ke c kak.

P : : Apakah nilai jarak tersebut sudah sesuai?

S1 : Iya kak sudah sesuai. Nilai jarak dari a ke c adalah $39 \mathrm{~km}$ kak.

$\mathrm{P} \quad$ : Coba kamu jelaskan, Bagaimana bisa terbukti!

S1 : Pertama-tama kan saya memakai rumus Pythagoras kak. Untuk a hasil dari 36 dikuadratkan adalah 1296 dan b hasil dari 15 dikuadratkan adalah 225. Maka hasil dari a+b adalah 1521 lalu diakarkan dan hasilnya $39 \mathrm{~km}$ kak. Karena dalam soal ditanyakan nilai jarak dari a ke c $39 \mathrm{~km}$, berarti sudah sesuai kak. 
Berdasarkan analisis hasil jawaban dan wawancara dengan S1 dapat disimpulkan bahwa S1 dalam menyelesaikan permasalahan no 4, memenuhi indikator penalaran matematis yaitu Memberikan alasan atau bukti terhadap kebenaran solusi dan masalah open-ended.

\section{Menyusun pembuktian langsung}

Dalam mengerjakan soal nomor lima peserta didik telah memenuhi indikator "menyusun pembuktian langsung" dalam menyelesaikan soal open-ended yang memiliki banyak cara untuk menjawabnya. Jawaban peserta didik ini pada Gambar 5 diberikan skor 3 dengan soal "Buktikan teorema Pythagoras dengan menggunakan persegi!". Karena peserta didik telah mampu membuktikan rumus pythagoras tetapi tidak menggunakan cara penyelesaian.

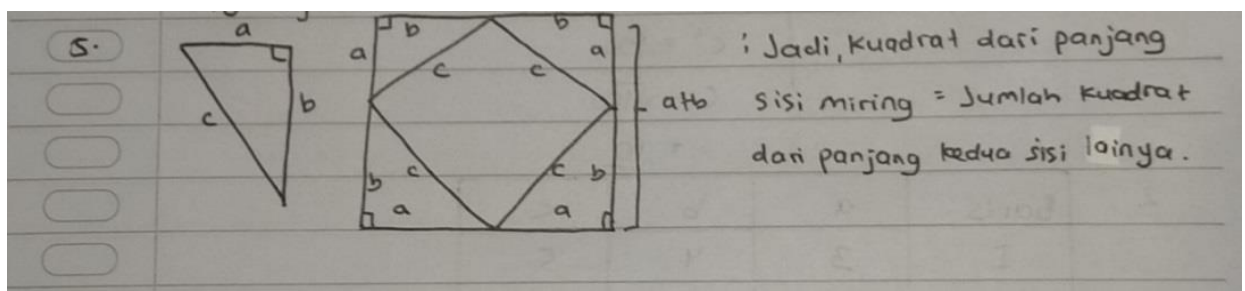

Gambar 5. Hasil Jawaban Peserta Didik yang Diberi Skor 3

Terkait dengan jawaban tersebut, dapat ditunjukan dalam wawancara dibawah ini :

P : Dapatkah kamu membuat pembuktian teorema Pythagoras?

S1 : Iya kak bisa.

P : : Coba jelaskan!

S1 : Pertama-tama saya membuat segitiga siku-siku dulu kak. Lalu segitiga tersebut dimasukkan kedalam persegi dan didapat4 segitiga siku-siku kak. Jadi kuadrat dari panjang sisi miring = jumlah kuadrat dari panjang kedua sisi lainnya.

$\mathrm{P} \quad$ : Bagaimana rumus Teorema Pythagoras itu ?

S1 : Rumus Pythagoras $c^{2}=a^{2}+b^{2}$ kak.

Berdasarkan analisis hasil jawaban dan wawancara dengan S1 dapat disimpulkan bahwa S1 dalam menyelesaikan permasalahan no 5, memenuhi indikator penalaran matematis yaitu Menyusun pembuktian langsung dan masalah open-ended namun ada satu pernyataan yang tidak benar.

Dari analisis hasil jawaban peserta didik dan wawancara tersebut, terlihat bahwa peserta didik sudah mampu menyelesaikan soal kemampuan penalaran matematis dalam penyajian masalah open-ended pada pembelajaran daring untuk materi teorema Pythagoras. Namun pada indikator pembuktian langsung peserta didik kurang mampu dalam memahami soal yang diberikan dan tidak mampu memberikan penjelasannya dari hasil jawaban.

\section{Simpulan}

Hasil dari penelitian ini adalah kemampuan penalaran matematis peserta didik pada pembelajaran daring sangat ditentukan ketika peserta didik menyelesaikan permasalahan, khususnya permasalahan open-ended. Hal ini dapat dilihat dari ketercapaian indikator kemampuan penalaran matematis yaitu menarik kesimpulan yang logis dengan persentase $77 \%$ kategori tinggi, membuat generalisasi dengan persentase $85 \%$ kategori sangat tinggi, memeriksa kesahihan dari pernyataan dengan persentase $68 \%$ kategori tinggi, memberikan alasan atau bukti terhadap kebenaran solusi dengan persentase $91 \%$ kategori sangat tinggi, dan menyusun pembuktian langsung dengan persentase $61 \%$ kategori tinggi. Dapat disimpulkan 
bahwa kemampuan penalaran matematis peserta didik dengan penyajian masalah open-ended di kelas VIII-A SMP Negeri 52 Jakarta pada pembelajaran daring memiliki kategori tinggi dengan persentase $76 \%$.

Saran yang akan disampaikan berdasarkan hasil dari penelitian ini adalah peserta didik diharapkan lebih dapat meningkatkan kemampuan penalaran matematis walaupun sudah termasuk kedalam kategori tinggi. Guru harus memfokuskan kemampuan penalaran matematis peserta didik, dengan cara melatih peserta didik menyelesaikan permasalahan open-ended yang bersifat pembuktian.

\section{Konflik Kepentingan}

Penulis menyatakan tidak ada konflik kepentingan

\section{Referensi}

Agarwal, S., \& Kaushik, J. S. (2020). Student's Perception of Online Learning during COVID Pandemic. Indian Journal of Pediatrics, 87(7), 554. https://doi.org/10.1007/s12098-020$\underline{03327-7}$

Basturk, S. (2010). First-year secondary school mathematics students' conceptions of mathematical proofs and proving. Educational Studies, 36(3), 283298. https://doi.org/10.1080/03055690903424964

Boesen, J., Lithner, J., \& Palm, T. (2010). The relation between types of assessment tasks and the mathematical reasoning students use. Educational Studies in Mathematics, 75(1), 89105. https://doi.org/10.1007/s10649-010-9242-9

Danişman, Ş., \& Erginer, E. (2017). The predictive power of fifth graders' learning styles on their mathematical reasoning and spatial ability. Cogent Education, 4(1). https://doi.org/10.1080/2331186X.2016.1266830

Dharmawansa, A. D., Nakahira, K. T., \& Fukumura, Y. (2013). Detecting eye blinking of a real-world student and introducing to the virtual e-Learning environment. Procedia Computer Science, 22, 717-726. https://doi.org/10.1016/j.procs.2013.09.153

Douglas, E. P., Koro-Ljungberg, M., McNeill, N. J., Malcolm, Z. T., \& Therriault, D. J. (2012). Moving beyond formulas and fixations: Solving open-ended engineering problems. European Journal of Engineering Education, 37(6), 627651. https://doi.org/10.1080/03043797.2012.738358

Faradillah, A. (2018). Analysis of Mathematical Reasoning Ability of Pre-Service Mathematics Teachers in Solving Algebra Problem Based on Reflective and Impulsive Cognitive Style. Formatif: Jurnal Ilmiah Pendidikan MIPA, 8(2), 119128. https://doi.org/10.30998/formatif.v8i2.2333

Fisher, D., Kusumah, Y. S., \& Dahlan, J. A. (2019). Junior High School Students' Mathematical Reasoning Ability Analysis in Systems of Linear Equations and Applications. Journal of Physics: Conference Series, 1315(1), 1-6. https://doi.org/10.1088/1742$\underline{6596 / 1315 / 1 / 012044}$ 
Flegas, K., \& Charalampos, L. (2013). Exploring Logical Reasoning and Mathematical Proof in Grade 6 Elementary School Students. Canadian Journal of Science, Mathematics and Technology Education, 13(1), 70-89. https://doi.org/10.1080/14926156.2013.758326

Gürbüz, R., \& Erdem, E. (2016). Relationship between mental computation and mathematical reasoningi. Cogent Education, 3(1). https://doi.org/10.1080/2331186X.2016.1212683

Hasanah, A., \& Karyati. (2018). The use of open ended problem in developing mathematical reasoning ability of junior high school students on geometry. International Conference on Mathematics and Science Education of Universitas Pendidikan Indonesia, 3, 763-767.

Ikram, M., Purwanto, \& Parta, I. N. (2021). Analisis Terjadinya Penalaran Reversibel Untuk Kasus Invers: Studi Kasus Pada Subjek Adjie. International Journal of Progressive Mathematics Education, 1(1), 1-15.

Imai, T. (2000). The influence of overcoming fixation in mathematics towards divergent thinking in open-ended mathematics problems on Japanese junior high school students. International Journal of Mathematical Education in Science and Technology, 31(2), 187193. https://doi.org/10.1080/002073900287246

Indriani, L. F., Yuliani, A., \& Sugandi, A. I. (2018). Analisis Kemampuan Penalaran Matematis dan Habits Of Mind Siswa SMP Dalam Materi Segiempat Dan Segitiga. Jurnal Math Educator Nusantara: Wahana Publikasi Karya Tulis Ilmiah Di Bidang Pendidikan Matematika, 4(2), 87-94. https://doi.org/10.29407/jmen.v4i2.11999

Johns, C., \& Mills, M. (2021). Online Mathematics Tutoring During the COVID-19 Pandemic: Recommendations for Best Practices. Primus, 31(1), 99117. https://doi.org/10.1080/10511970.2020.1818336

Konita, M., Asikin, M., \& Noor Asih, T. S. (2019). Kemampuan Penalaran Matematis dalam Model Pembelajaran Connecting , Organizing , Reflecting , Extending. PRISMA,Prosiding Seminar Nasional Matematika, 2, 611-615.

Kosiret, A., Indiyah, F. H., \& Wijayanti, D. A. (2021). Peningkatan Kemampuan Pemahaman Konsep Matematis Siswa SMA Islam Al-Azhar 19 Dengan menggunakan Model Pembelajaran Generatif. International Journal of Progressive Mathematics Education, 1(1), 16-26.

Kosyvas, G. (2016). Levels of arithmetic reasoning in solving an open-ended problem. International Journal of Mathematical Education in Science and Technology, 47(3), 356372. https://doi.org/10.1080/0020739X.2015.1072880

Landrum, B., Bannister, J., Garza, G., \& Rhame, S. (2020). A class of one: Students' satisfaction with online learning. Journal of Education for Business, 0(0), 17. https://doi.org/10.1080/08832323.2020.1757592

Littlejohn, A. (2003). Supporting sustainable e-learning. Journal of Education for Business, 11(3), 88-102. https://doi.org/10.1080/0968776030110308

Morris, A. K. (2002). Mathematical reasoning: Adults' ability to make the inductive-deductive 
Cognition

and

Instruction,

20(1),

118. https://doi.org/10.1207/S1532690XCI2001_4

Nabilah, E., Azhar, E., Purwanto, S. E., \& Nabilah, E. (2021). Kecemasan Siswa Dalam Menyelesaikan Masalah Modelling Matematika Pada Praktek Kelas Virtual. 1(1).

Octaviani, K. D., Indrawatiningsih, N., \& Afifah, A. (2021). Kemampuan Visualisasi Spasial Siswa Dalam Memecahkan Masalah Geometri Bangun Ruang Sisi Datar Kemampuan Visualisasi Spasial Siswa Dalam Memecahkan Masalah Geometri Bangun Ruang Sisi Datar. International Journal of Progressive Mathematics Education, 1(1), 27-40.

Olteanu, C. (2020). Programming, mathematical reasoning and sense-making. International Journal of Mathematical Education in Science and Technology, 119. https://doi.org/10.1080/0020739x.2020.1858199

Partanen, P., Jansson, B., \& Sundin, Ö. (2020). Fluid reasoning, working memory and planning ability in assessment of risk for mathematical difficulties. Educational Psychology in Practice, 36(3), 229-240. https://doi.org/10.1080/02667363.2020.1736518

Psycharis, S., \& Kallia, M. (2017). The effects of computer programming on high school students' reasoning skills and mathematical self-efficacy and problem solving. Instructional Science, 45(5), 583-602. https://doi.org/10.1007/s11251-017-9421-5

Rizqi, N.R., \& Surya, E. (2017). An Analysis of Students' Mathematical Reasoning Ability In VIII Grade of Sablina Tembung Junior High School. International Journal of Advance Research and Innovative Ideas in Education (IJARIIE), 3(2 2017), 35273533. http://www.mendeley.com/research/6031c8fb-6049-3895-a27e-9fe7a6ce3126/

Robbins, J. K. (2011). Problem solving, reasoning, and analytical thinking in a classroom environment. The Behavior Analyst Today, 12(1), 4148. https://doi.org/10.1037/h0100710

Rohana. (2015). The enhancement of student' $s$ teacher mathematical reasoning ability through reflective learning. Journal of Education and Practice, 6(20), 108-115.

Santosa, F. H., Negara, H. R. P., \& Samsul Bahri. (2020). Efektivitas Pembelajaran Google Classroom Terhadap Kemampuan Penalaran Matematis Siswa. Jurnal Pemikiran Dan Penelitian Pendidikan Matematika (JP3M), $\quad 3(1), \quad 62-$ 70. https://doi.org/10.36765/jp3m.v3i1.254

Sole, M. A. (2016). Multiple Problem-Solving Strategies Provide Insight into Students' Understanding of Open-Ended Linear Programming Problems. Primus, 26(10), 922937. https://doi.org/10.1080/10511970.2016.1199621

Sukirwan, Darhim, D., \& Herman, T. (2018). Analysis of students' mathematical reasoning. Journal of Physics: Conference Series, 948(1). https://doi.org/10.1088/1742$\underline{6596 / 948 / 1 / 012036}$

Syutaridho, M. (2015). Pengembangan Soal Open Ended Pada Pokok Bahasan Pythagoras. Jurnal Pendidikan Matematika JPM RAFA, 1(1), 118-139.

Tan, S., \& Maker, C. J. (2020). Assessing creative problem solving ability in mathematics: The 
DISCOVER Mathematics Assessment. Gifted and Talented International, 35(1), 5871. https://doi.org/10.1080/15332276.2020.1793702

Tandililing, E. (2013). Pengembangan Kemampuan Koneksi Matematis Siswa Melalui Pendekatan Advokasi Dengan Penyajian Masalah Open-Ended Pada Pembelajaran Matematika. Makalah Dipresentasikan Dalam Seminar Nasional Matematika Dan Pendidikan Matematika Dengan Tema "Penguatan Peran Matematika Dan Pendidikan Matematika Untuk Indonesia Yang Lebih Baik" Pada Tanggal 9November 2013 Di Jurusan Pendidikan Matematika FMIPA UNY, 203-210. 